\title{
Sediment thickness in the Bay of Bengal and Andaman Sea compared with topography and geophysical settings by GMT
}

\author{
Polina Lemenkova
}

\begin{abstract}
The study presents an analysis of the sediment thickness compared with bathymetric and geophysical settings in the Bay of Bengal and Andaman Sea, Indian Ocean. It uses a combination of the high-resolution data: topographic GEBCO, satellite and marine gravity anomalies, EGM2008 geoid and GlobSed to visualize the correlation between relief, gravity and trends in continent-ocean sediment transport. The results include thematic maps and 3D model showing increased sediment thickness in the Bengal Fan $(8,0$ to $8,2 \mathrm{~km})$ in NE direction with maximum in Ganges Fan $(16,2 \mathrm{~km})$, and southward decrease in the Andaman Sea from Irrawaddy river mouth $(6-7 \mathrm{~km})$ to the Strait of Malacca (1-2 km). All maps and 3D model have been plotted by Generic Mapping Tools (GMT) cartographic scripting toolset version 6.0.0.
\end{abstract}

Keywords - Andaman Sea, Bay of Bengal, cartography, sediment thickness

\section{INTRODUCTION}

The paper examines the sediment accumulation in the basins of the Bay of Bengal and the Andaman Sea compared with the geological and topographic settings in the study area, Fig. 1. The seafloor here shows diverse pattern of the distribution of sediments that have the highest values near the coasts and shelf areas and the thinnest layer near the open sea basins, mid-ocean ridges, spreading centres and younger seafloor and. On the contrary, thicker sediment layer is near the older seafloor where they accumulated over time.

The sedimentary cover in the oceanic basins has generally continuous distribution of sediments accumulated as strata in the basins. The exception is presented by the slopes of the submarine elevations and seamounts. Sediment thickness gradually increases towards the continental margins, generally ranging from 0.5 to $1.0-1.5 \mathrm{~km}$ [1]. However, the Bay of Bengal is notable for the exceptionally high sediment thickness caused by the long-term intensive inflow of the material from the adjacent continental margins. In the eastern part of the Bay of Bengal, the thickness of the sedimentary cover is about 2-3 km, in the western parts it exceeds $3 \mathrm{~km}$ and sharply increases in the pre-continental troughs, reaching more than $7 \mathrm{~km}$ in the western part of the Bay of Bengal and in its northern part (mouth of the Ganges river) - over $15 \mathrm{~km}$ (Fig. 2).

Origin of the terrigenous sedimentation include transfer of the materials from the adjacent coasts, transportation, deposition and dislocation of the sediments [2]. The origin of the deep-sea sedimentation is diverse. A key pathway for sediment transfer on Earth is the land-ocean transfer of sediment by rivers including the major role of the anthropogenic 
factors. These includes the increased sediment loads and river fluxes from the agriculture activities, land surface processing, logging and mining [3]. Major rivers contributing to these activities include Ganges, Krishna, Mahanadi, Godavari (India) and Irrawaddy (Myanmar). Apart from the riverine sediments, other sources include glaciers melting, dust moved by the aeolian processes and storms [4].

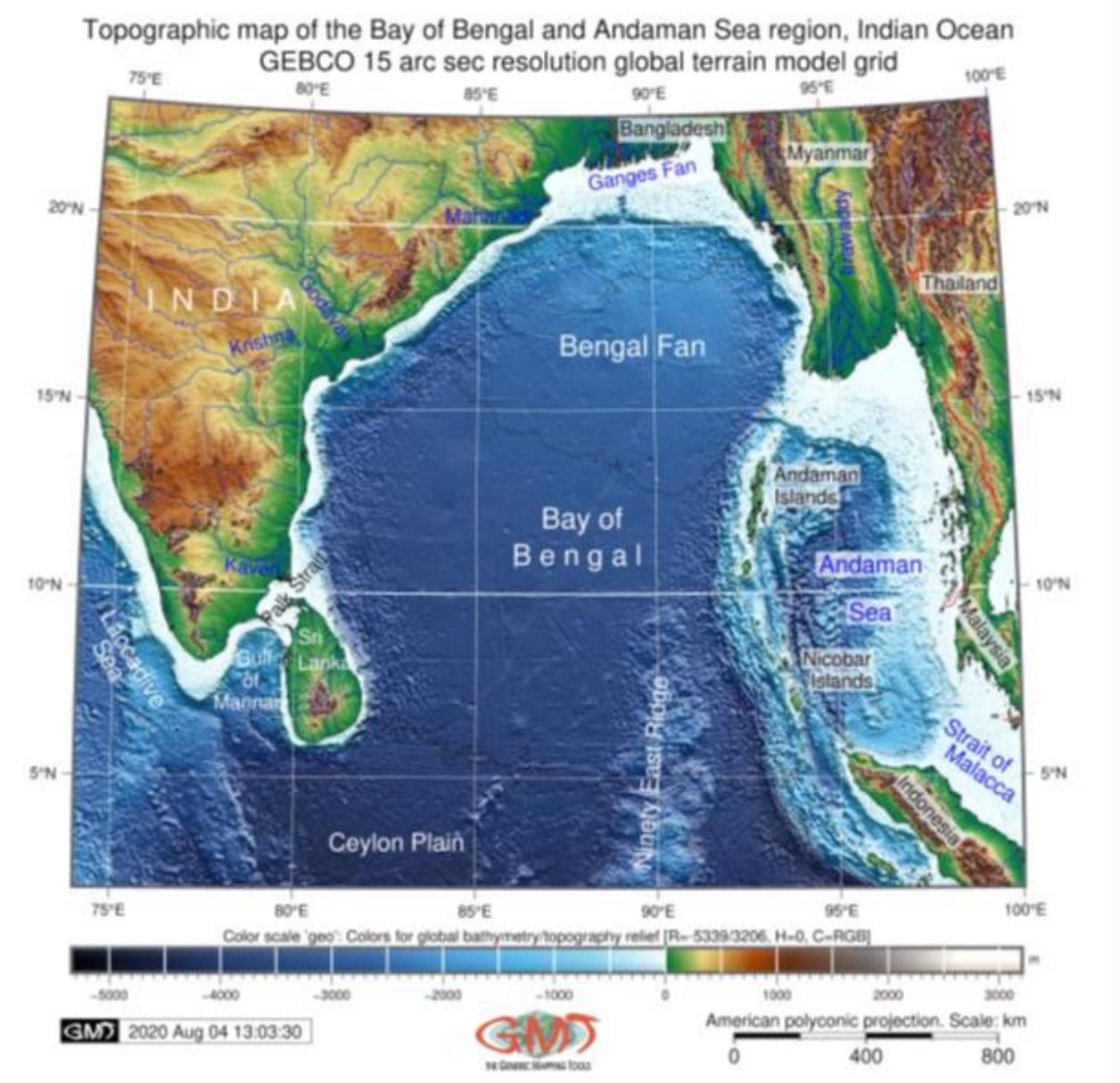

Fig. 1. Topographic map of the Bay of Bengal and Andaman Sea. Source: author

Bathymetry play important role in the intensity of filling of the negative relief forms by sediments. The seafloor of the troughs and trenches can form a certain threshold which serves as a dam, in front of which a thicker sediment layer is being accumulated. Therefore, the streams of the sediments moving over the seafloor closer to the continent with flatter relief are being accumulated more intensively compared to the areas with complex topographic structure [5]. Geophysical effects can be illustrated by the sediment response to the acting forces of gravity.

To generalize, the formation of sediments can be induced by the following factors [6]:

1. Land weathering (terrigenous material) 


\section{sciendo}

Ovidius University Annals Series: Civil Engineering, Year 22, 2020

2. Biogenic processes and accumulation of shells and tissues

3. River runoff transferring sediments to the ocean basins

The processes of partial deposition, stratification and differentiation of the sediments along the transport paths to the final runoff into basins takes place in accordance with complex formulae defined by mathematical foundations of gravity [7]. Geospatial factors include physical and topographic settings, hydrological characteristics of the water column and chemical characteristics of the sedimentary material which is reflected in the transformation of the deposited materials into sedimentary rocks. The link between the sediment accumulation with topographic factors, geological and geophysical settings can be studied using multi-sources data analysis and overlay of raster grids using advanced cartographic solutions [8]-[10]. Such work is required to provide a quantitative assessment and cartographic visualization of the thematic layers affecting seafloor sedimentation processes. Local settings of the Bay of Bengal include high erosion rates in the Himalayas which ultimately generate high sedimentation rates in the Bay of Bengal [11].

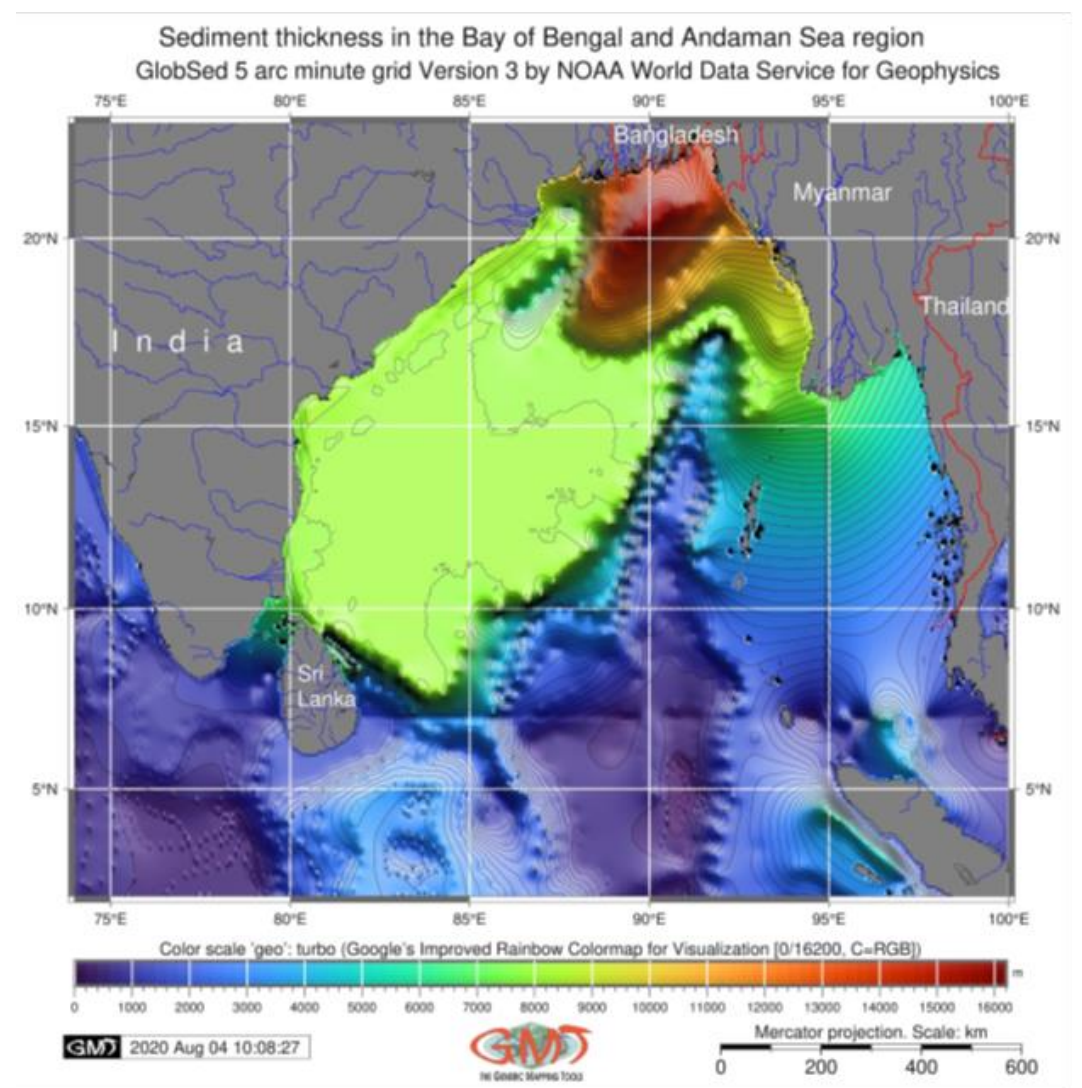

Fig. 2. Sediment thickness of the Bay of Bengal and Andaman Sea. Source: author

Other important factors include mineralogical and chemical differences between sediment particles of rivers which in turn are associated with hydraulically controlled compositional variability of fluvial sediments entering the Bay of Bengal and the Andaman Sea [12]. 
16 Ovidius University Annals Series: Civil Engineering, Year 22, 2020

\section{EXPERIMENT DESCRIPTION}

The methodological framework addressed in this study and proposed by existing works [13]-[15], develops a GMT based approach [16]. The GEBCO dataset [17] has been used in order to visualize a series of topographic grid (Fig. 1) as well as ETOPO5 [18] for 3D modelling (Fig. 2). The geophysical and geological grids include EGM2008 geoid grid [19] for visualized geoid of the Bay of Bengal and the Andaman Sea (Fig. 5) and satellite derived CryoSat-2 and Jason-1 marine free-air gravity anomaly grid [20] shown on Fig. 4. The sediment thickness GlobSed grid [21] was used to compare spatial variability of the sediment thickness in the basins of the Andaman Sea and the Bay of Bengal (Fig. 2).

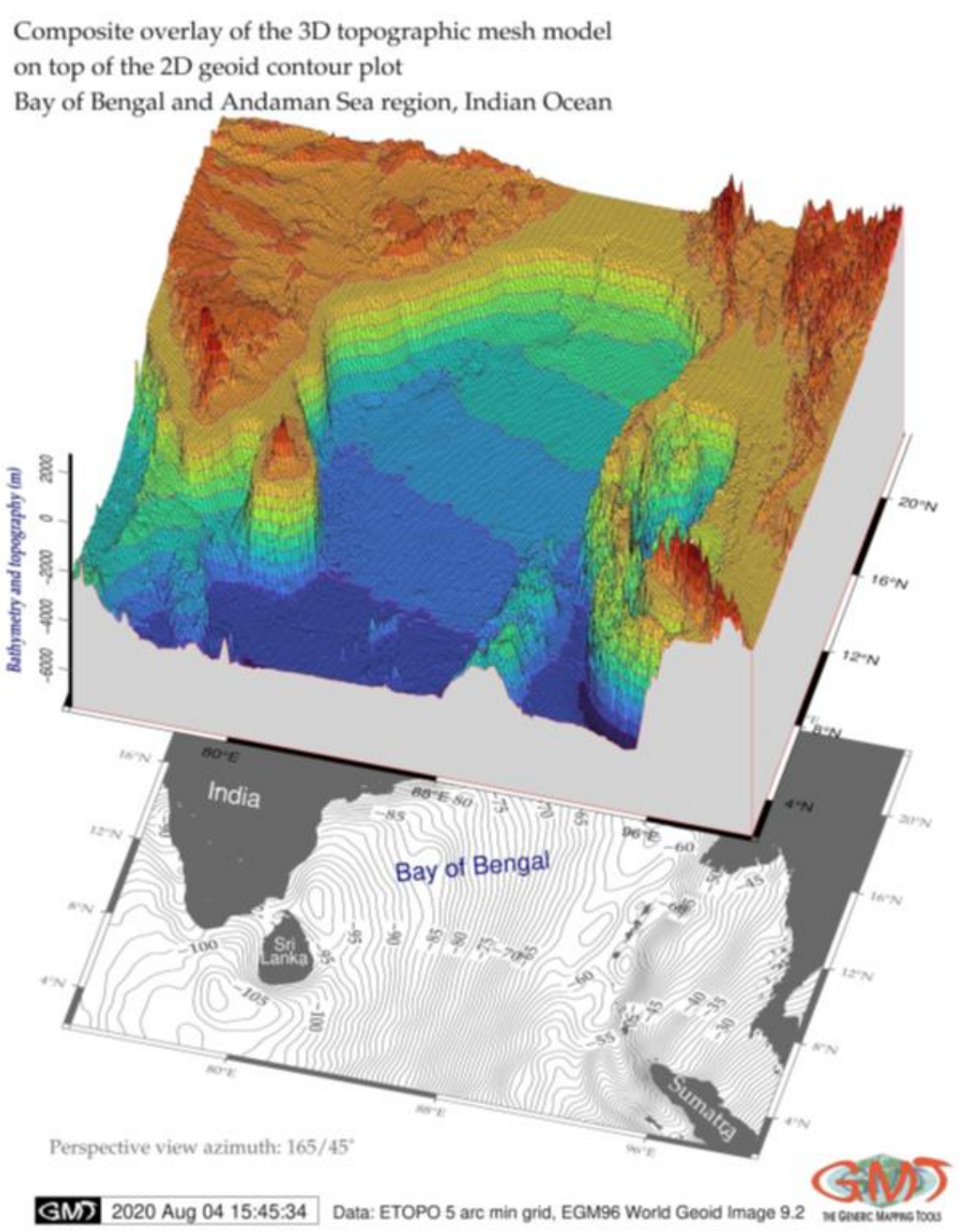

Fig. 3. 3D relief model of the Bay of Bengal and Andaman Sea. Source: author 


\section{sciendo}

Ovidius University Annals Series: Civil Engineering, Year 22, 2020

Combination of such multi-sources data enables to assess the relative degree of correlation between these phenomena (geology, tectonics evolution, topographic relief and sedimentations processes) that confirms the area of direct and indirect influence affecting the sediment inflow into the basins of the Andaman Sea and the Bay of Bengal.

\section{RESULTS AND SIGNIFICANCES}

Principal results include cartographic modelling and mapping of the raster datasets including sediment thickness, bathymetry, marine free-air gravity anomaly, geoid undulations and 3D model (Fig. 3) demonstrating the relief DEM as a three-dimensional transect.

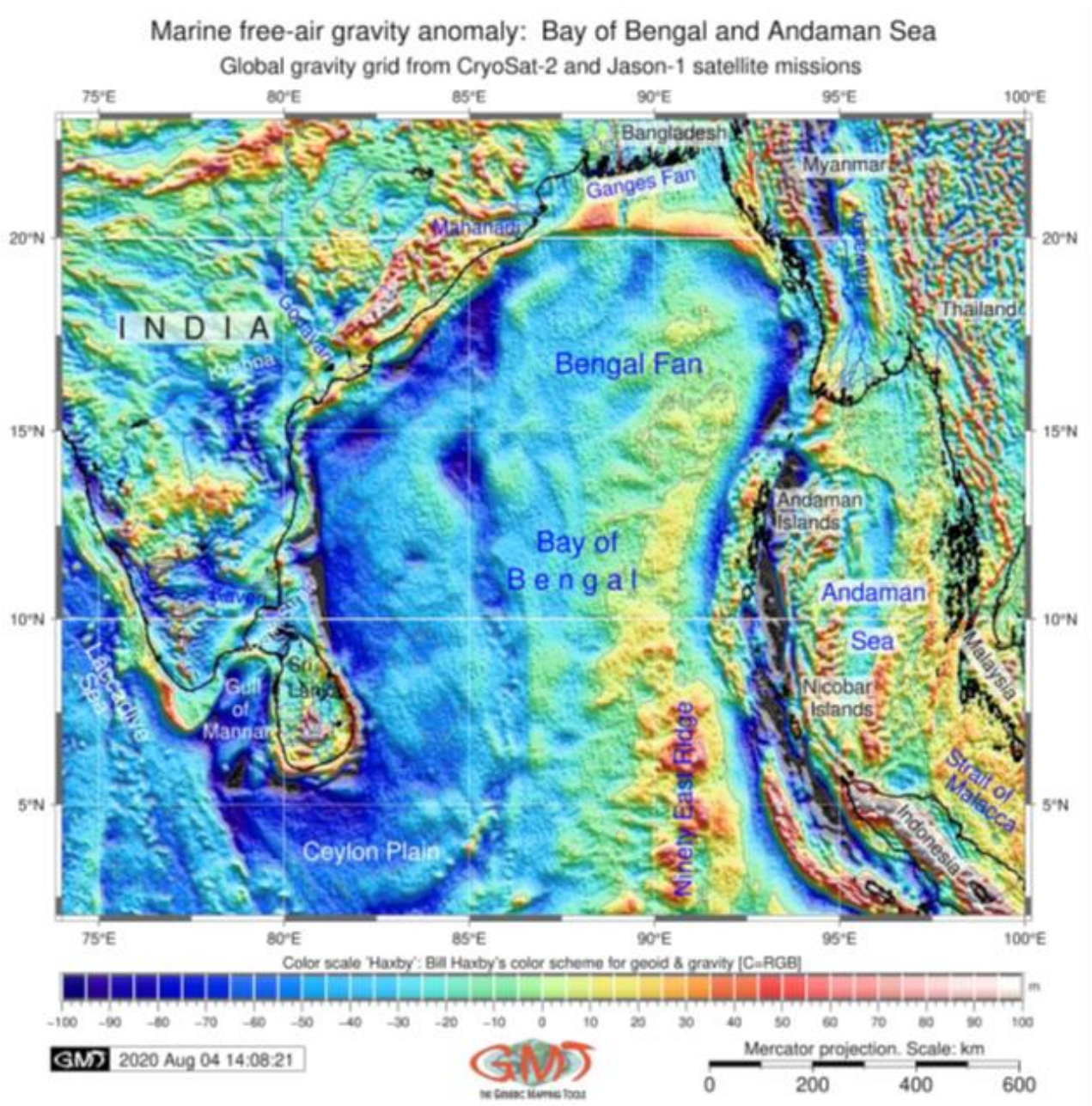

Fig. 4. Marine free-air gravity anomalies in the study area. Source: author 
Multi-source high-resolution data analysis is crucial in both linking the processes between sedimentation and impact factors affecting its variation and regional studies of the shelf area of the northern Indian Ocean.

Besides, it provides a technical assessment of concentration for sediments using highresolution grids with the topographic effects, closeness of the continental slope and geophysical values.

The topography of the region is visualized as a map (Fig. 1) and a 3D model (Fig. 3) showing the diverse relief of the Bay of Bengal and the Andaman Sea.

The Andaman Sea separated from the Bay of Bengal to its west by the Andaman Islands and the Nicobar Islands has a smaller basin [22]. Tectonically, the Andaman Sea was formed as the result of highly oblique subduction at the western Sunda Trench [23].

A lower marine free-air gravity values $(<-70 \mathrm{mGal})$ with a very steep gradient lie directly over the forearc basin (Fig. 4). Comparing to the Bay of Bengal, the gravity anomalies have a trend of gradual decrease in westward direction. For instance, values over $40 \mathrm{mGal}$ above the Ninety East Ridge against below $-70 \mathrm{mGal}$ along the eastern coasts of India (Fig. 4).

The basins of the northern part of the Indian Ocean are characterized by a presence of the highly stratified sediments, where terrigenous deposits play an important role, especially in the north, near the continental margin.

In the southern parts of the Bay of Bengal, the basal deposits origin of Paleocene and Eocene age, respectively.

In the southern part of the Bay of Bengal, there are sandy-argillaceous deposits from the Pleistocene, Middle Miocene, Lower Cretaceous overly the basalt basement.

The basins of the southern part of the Bay of Bengal and the Ceylon Plain are characterized by a small thickness of the sedimentary cover from 0.1 to $0.5 \mathrm{~km}$ (dark blue areas on Fig. 2).

The sediment thickness in the Andaman Sea is determined by the influx of the huge masses of the sedimentary material from the Irrawaddy river and ridges of the Andaman and Nicobar Islands separating the sea from the Bay of Bengal.

The eastern part of the Andaman Sea is shallow (Fig. 1 and 3) with limited sedimentation processes [24]. On the contrary, the isolines of the sediments show gradual increase in sedimentation northwards reaching up to $9-10 \mathrm{~km}$ (light orange colours, Fig. 2).

The area of the greatest depths $>3000 \mathrm{~m}$ ) is located near the Andaman and Nicobar islands ridge. Only near the mouth of Irrawaddy sedimentation rates are very high. In the western, deeper part of the Andaman Sea, the average value of the sediment thickness is high $(7-8 \mathrm{~km})$, in some places exceeds $9 \mathrm{~km}$.

The highest values tend to the northern parts of the basin, closer to the Irrawaddy mouth. The dominant role in sedimentation of the Andaman Sea is the supply of terrigenous sediments from Irrawaddy.

The trend of the geoid undulation (Fig. 5) is controlled by main directions: W-E and S-N.

The SN-oriented segment can clearly be seen on the segment $75^{\circ}-80^{\circ} \mathrm{E}$ in northward direction (a transect Sri Lanka up to Himalaya), which is related to the geophysical settings and rock properties, formed during the geological evolution.

In contrast, the WE segment exhibits from the Strait of Malacca to the Laccadive Sea at $5^{\circ}-10^{\circ} \mathrm{N}$, with a changing geoid height from slightly negative values $(-10 \mathrm{~m}$ around Sumatra, Andaman Sea) to above $-110 \mathrm{~km}$ (SW off Sri Lanka), Fig. 5.

The Bengal Fan shows gradual decrease in geoid height in a SW direction (from -58 to -96$)$, Fig. 5. 


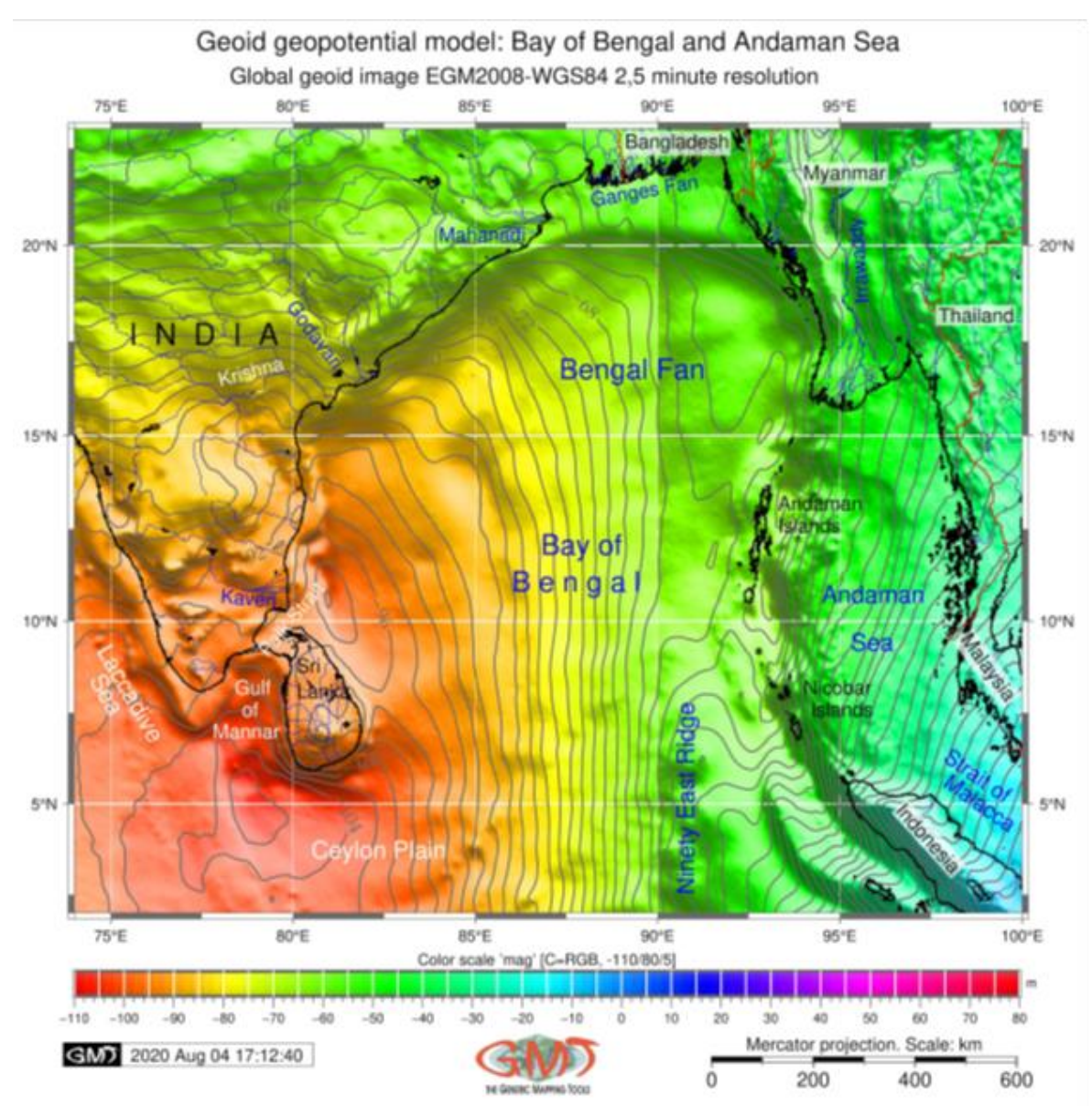

Fig. 5. Geoid model: Bay of Bengal and Andaman Sea. Source: author

\section{CONCLUSIONS}

As demonstrated, the Bengal Bay, a complex foreland basin southward of Himalayas, shows string variability in sediment thickness that reflects a complicated depositional and tectonic history which is also supported by findings in previous works [25]-[30].

The increasing intensity of automatization in cartographic processes [30]-[32] makes GMT scripting toolset as especially effective instrument for geodata visualization.

Comparing to the traditional GIS [33]-[35], the progressively changing methodology of the mapping approaches in GMT gradually replaces manual routine of GIS by scripting approaches and using programming languages in geological data analysis.

\section{ACKNOWLEDGEMENTS}

This research has been supported and implemented in the framework of the Project No. 0144-2019-0011, Schmidt Institute of Physics of the Earth, Russian Academy of Sciences. I thank the anonymous reviewers and editors for the review of the manuscris. 
sciendo $_{20}$ Ovidius University Annals Series: Civil Engineering, Year 22, 2020

\section{REFERENCES}

[1] Bezrukov, P.L., Neprochnov, Y.P. (1981), Geology and geophysics of the bottom of the eastern part of the Indian Ocean. Moscow, Nauka, $256 \mathrm{pp}$

[2] Lemenkova, P., (2020), Integration of geospatial data for mapping variation of sediment thickness in the North Sea. Scientific Annals of the Danube Delta Institute, 25, 129-138

[3] Walling, D.E., (2006), Human impact on land-ocean sediment transfer by the world's rivers. Geomorphology 79 (3-4), 192-216

[4] Lemenkova, P. (2019), Statistical Analysis of the Mariana Trench Geomorphology Using R Programming Language. Geodesy and Cartography, 45(2), 57-84

[5] Lemenkova, P. (2019), An Empirical Study of R Applications for Data Analysis in Marine Geology. Marine Science and Technology Bulletin, 8(1), 1-9

[6] Garcia, M. 2008. Sedimentation Engineering: Processes, Measurements, Modeling, and Practice. American Society of Civil Engineers, 1132p. ISBN: 978-0-7844-0814-8

[7] Bustos, M.C., Concha, F., Bürger, R, Tory, E.M., 1999. Sedimentation and Thickening: Phenomenological Foundation and Mathematical Theory, Kluwer Academic Publishers, Dordrecht, The Netherlands, 285 pp. ISBN 0-7923-5960-7

[8] Lemenkova, P. (2020), GMT Based Comparative Geomorphological Analysis of the Vityaz and Vanuatu Trenches, Fiji Basin. Geodetski List, 74(1), 19-39

[9] Lemenkova, P., (2020), Variations in the bathymetry and bottom morphology of the Izu-Bonin Trench modelled by GMT. Bulletin of Geography. Physical Geography Series, 18(1), 41-60

[10] Lemenkova, P. (2019), Geophysical Modelling of the Middle America Trench using GMT. Annals of Valahia University of Targoviste. Geographical Series, 19(2), 73-94

[11] Galy, V., France-Lanord, C., Beyssac, O., Faure, P., Kudrass, H., Palhol, F., (2007), Efficient organic carbon burial in the Bengal fan sustained by the Himalayan erosional system. Nature, 450 (7168), 407

[12] Garzanti, E., Andò, S., France-Lanord, C., Vezzoli, G., Censi, P., Galy, V., Najman, Y., (2010). Mineralogical and chemical variability of fluvial sediments. 1. Bedload sand (GangaBrahmaputra, Bangladesh). Earth and Planetary Science Letters, 299 (3-4), 368-381

[13] Lemenkova, P. (2019), Geomorphological modelling and mapping of the Peru-Chile Trench by GMT. Polish Cartographical Review, 51(4), 181-194

[14] Lemenkova, P. (2019), Topographic surface modelling using raster grid datasets by GMT: example of the Kuril-Kamchatka Trench, Pacific Ocean. Reports on Geodesy and Geoinformatics, 108, 9-22

[15] Lemenkova, P. (2019), GMT Based Comparative Analysis and Geomorphological Mapping of the Kermadec and Tonga Trenches, Southwest Pacific Ocean. Geographia Technica, 14(2), 39-48

[16] Wessel, P., Smith, W.H.F., Scharroo, R., Luis, J.F., Wobbe, F. (2013), Generic mapping tools: Improved version released. Eos Transactions American Geophysical Union, 94(45), 409-410

[17] GEBCO Compilation Group (2020), GEBCO 2020 Grid. DOI: 10.5285/a29c5465b138-234d-e053-6c86abc040b9

[18] Data Announcement 88-MGG-02, 1988. Digital relief of the Surface of the Earth. NOAA, National Geophysical Data Center, Boulder, Colorado

[19] Pavlis, N.K., Holmes, S.A., Kenyon, S.C. \& Factor, J.K. (2012), The development and evaluation of the Earth Gravitational Model 2008 (EGM2008). Journal of Geophysical Research, 117, B04406 
[20] Sandwell, D.T., Müller, R.D., Smith, W.H.F., Garcia, E., Francis, R., (2014), New global marine gravity model from CryoSat-2 and Jason-1 reveals buried tectonic structure. Science, 346 (6205), 65-67

[21] Straume, E.O., Gaina, C., Medvedev, S., Hochmuth, K., Gohl, K., Whittaker, J.M., Abdul Fattah, R., Doornenbal, J.C., Hopper, J.R. 2019. GlobSed: Updated total sediment thickness in the world's oceans. Geochemistry, Geophysics, Geosystems, 20

[22] Rodolfo K. S. 1969, Bathymetry and marine geology of the Andaman basin and tectonic implications for Southern Asia. Geological Society of America Bulletin, 8, 1203-1230

[23] Cochran, J.R. (2010), Morphology and tectonics of the Andaman Forearc, northeastern Indian Ocean. Geophysical Journal International, 182(2), 631-651.

[24] Rodolfo K. S. 1969, Sediments of the Andaman Sea basin, Northeastern Indian ocean. Marine Geology, 7, 371-402

[25] Uddin, A., Lundberg, N., 2004, Miocene sedimentation and subsidence during continentcontinent collision, Bengal basin, Bangladesh. Sedimentary Geology, 164, 131-146

[26] Garzanti, E., Andó, S., France-Lanord, C., Censi, P., Vignola, P., Galy, V., Lupker, M., 2011. Mineralogical and chemical variability of fluvial sediments 2. Suspended-load silt (Ganga-Brahmaputra, Bangladesh). Earth and Planetary Science Letters, 302 (1-2), 107-120 [27] Stummeyer, J., Marchig, V., Knabe, W., (2002), The composition of suspended matter from Ganges-Brahmaputra sediment dispersal system during low sediment transport season. Chemical Geology, 185 (1-2), 125-147

[28] Curray, J.R. (2005), Tectonics and history of the Andaman Sea region. Journal of Asian Earth Sciences, 25(1), 187-232

[29] Jourdain, A., Singh, S.C., Escartin, J., Klinger, Y., Raju, K.A.K., Mcardle, J. (2016), Crustal accretion at a sedimented spreading centre in the Andaman Sea, Geology, 44(5), 351-354

[30] Schenke, H. W., Lemenkova, P. (2008). Zur Frage der Meeresboden-Kartographie: Die Nutzung von AutoTrace Digitizer für die Vektorisierung der Bathymetrischen Daten in der Petschora-See. Hydrographische Nachrichten, 81, 16-21

[31] Lemenkova, P., (2020), $R$ Libraries \{dendextend\} and \{magrittr\} and Clustering Package scipy.cluster of Python For Modelling Diagrams of Dendrogram Trees. Carpathian Journal of Electronic and Computer Engineering, 13(1), 5-12

[32] Lemenkova, P. (2019), AWK and GNU Octave Programming Languages Integrated with Generic Mapping Tools for Geomorphological Analysis. GeoScience Engineering, 65(4), 1-22

[33] Klaučo, M., Gregorová, B., Stankov, U., Marković, V., Lemenkova, P. (2013). Determination of ecological significance based on geostatistical assessment: a case study from the Slovak Natura 2000 protected area. Open Geosciences, 5(1), 28-42

[34] Suetova, I. A., Ushakova, L. A., Lemenkova, P. (2005). Geoinformation mapping of the Barents and Pechora Seas. Geography and Natural Resources, 4, 138-142

[35] Lemenkova, P. (2011). Seagrass Mapping and Monitoring Along the Coasts of Crete,

Greece. M.Sc. Thesis. Netherlands: University of Twente. 158 pp

Note:

Lemenkova Polina - Schmidt Institute of Physics of the Earth, Russian Academy of Sciences. Department of Natural Disasters, Anthropogenic Hazards and Seismicity of the Earth. Laboratory of Regional Geophysics and Natural Disasters (Nr. 303). Bolshaya Gruzinskaya St, 10, Bld. 1, Moscow, 123995, Russian Federation. ORCID ID: https://orcid.org/0000-0002-5759-1089 Tel.: +007-916-298-37-19. e-mail: pauline.lemenkova@gmail.com 